Syntax Idea: p-ISSN: 2684-6853 e-ISSN: 2684-883X

Vol. 3, No. 7, Juli 2021

\title{
KONSEP KEADILAN RESTORATIF DALAM PENEGAKAN HUKUM PIDANA DI MASA PANDEMI COVID 19
}

\section{Muhammad Rafi Urrutab}

Universitas Islam Indonesia (UII) Yogyakarta, Indonesia

Email: rafiurrutab28@gmail.com

\begin{abstract}
Abstrak
Penegakan keadilan dalam kehidupan bermasyarakat memiliki arti yang sangat penting dalam upaya membangun peradaban bangsa yang tinggi dan bermartabat. Hal ini berkaitan erat dengan kondisi pandemi covid 19 yang masih terus meningkat dan menimbulkan banyak korban. Tidak hanya korban jiwa, tetapi juga berpengaruh pada aspek lainnya seperti kehidupan ekonomi, sosial masyarkat, pendidikan, sampai pada aspek keagamaan. Sejalan dengan hal itu, melalui Peraturan Kejaksaan Republik Indonesia Nomor 15 Tahun 2020 Tentang Penghentian Penuntutan Berdasarkan Keadilan Restoratif, instansi kejaksaan berupaya untuk mengedapankan nilai-nilai keadilan dalam uapaya menghasilkan produk hukum yang lebih berkeadilan dengan memerhatikan kondisi dari para pihak terutama korban dan pelaku kejahatan sehingga jalur pidana bukan satusatunya jalan utama yang ditempuh. Oleh karena itu, penelitian ini akan mengkaji beberapa rumusan permasalahan diantaranya adalah bagaimana konsep keadilan restoratif dalam Peraturan Kejaksaan Republik Indonesia Nomor 15 Tahun 2020 Tentang Penghentian Penuntutan Berdasarkan Keadilan Restoratif serta urgensinya dalam penegakan hukum pidana di masa pandemi Covid 19. Penelitian ini merupakan penelitian hukum yuridis-normatif dengan metode pengumpulan data yaitu studi pustaka dan analisis secara deskriptif-kualitatif dengan pendekatan filosofis yuridis. Kesimpulan penelitian ini yaitu secara muatan hukum, Peraturan Kejaksaan Republik Indonesia Nomor 15 Tahun 2020 Tentang Penghentian Penuntutan Berdasarkan Keadilan Restoratif sudah cukup memenuhi aspek keadilan serta memenuhi prinsip-prinsip umum keadilan restoratif. Namun demikian, perlu adanya beberapa perbaikan seperti penjelasan terkait konteks kasuistik dalam Pasal 5 dan impelementasi peraturan bagi aparat penegak hukum agar senantiasa mengedepankan hati nurani sehingga penegakan hukum di Indonesia kedepan semakin baik serta mampu mengembalikan kepercayaan publik dalam upaya penegakan hukum dan keadilan. Selain itu, di tengah masa pandemi, konsep ini sejalan dengan aturan pemerintah dalam upaya menanggulangi pandemi covid 19 sehingga tidak semua kejahatan harus diselesaikan secara pidana sebagaimana kondisi lembaga pemasyarakatan di Indonesia yang sudah melebihi kapasitas.
\end{abstract}

Kata Kunci: keadilan restoratif; peraturan; kejaksaan; urgensi; Covid 19

\section{Abstract}

The enforcement of justice in social life has a very important meaning in an effort to build a high and dignified nation's civilization. This is closely related to the 
condition of the COVID-19 pandemic which is still increasing and causing many victims. Not only casualties, but also affects other aspects such as economic life, social life, education, to the religious aspect. In line with this, through the Regulation of the Attorney General of the Republic of Indonesia Number 15 of 2020 concerning Termination of Prosecution Based on Restorative Justice, the prosecutor's office seeks to promote the values of justice in an effort to produce legal products that are more just by taking into account the conditions of the parties, especially victims and perpetrators of crime so that the criminal route is not the only way to go. Therefore, this study will examine several formulations of the problem including how the concept of restorative justice in the Republic of Indonesia Prosecutor's Regulation Number 15 of 2020 concerning Termination of Prosecution Based on Restorative Justice and its urgency in criminal law enforcement during the Covid 19 pandemic. This research is a juridical law research. -normative data collection method, namely literature study and descriptive-qualitative analysis with a juridical philosophical approach. The conclusion of this study is that in terms of legal content, the Regulation of the Attorney General of the Republic of Indonesia Number 15 of 2020 concerning Termination of Prosecution Based on Restorative Justice is sufficient to meet the aspects of justice and meet the general principles of restorative justice. However, some improvements are needed, such as an explanation related to the casuistic context in Article 5 and the implementation of regulations for law enforcement officers to always prioritize conscience so that law enforcement in Indonesia will be better in the future and able to restore public trust in law enforcement and justice. In addition, in the midst of a pandemic, this concept is in line with government regulations in an effort to overcome the covid 19 pandemic so that not all crimes must be resolved criminally as the conditions of prisons in Indonesia have exceeded their capacity.

Keywords: restorative justice; regulations; attorney; urgency; Covid 19

\section{Pendahuluan}

Gejala dari pandemi Covid 19 menimbulkan masalah di berbagai sektor seperti pengangguran akibat lonjakan pemutusan hubungan kerja (PHK), kelangkaan pangan dan naiknya harga pangan, serta diferensiasi distribusi bantuan pangan tidak merata. Hal ini memicu rantai endemik kriminalitas atau impresi kriminal dari dan untuk manusia. Salah satu kejahatan yang muncul di masa pandemi Covid 19 ini adalah meningkatnya tindak kejahatan yang pada dasarnya hanya untuk memenuhi kebutuhan sehari-hari (Burhanuddin, Massi, Thahir, Razak, \& Surungan, 2020).

Pandemi Covid 19 mengakibatkan ekonomi kian tergerus. Hal ini memengaruhi kehidupan masyarakat terutama keluarga yang secara ekonomi kurang mampu dan pekerjaannya terganggu dengan adanya pandemi Covid 19. Selain itu, secara psikologis massa, kondisi yang semakin buruk ini memberi dampak timbulnya gejolak feeling the heat yaitu perasaan atau situasi yang tidak nyaman dari kondisi ekstrim tersebut sehingga seseorang bisa melakukan tindakan kekerasan pada siapapun terutama pada orang terdekatnya dan dianggap lemah. Hal ini sejalan dengan pendapat Filsuf Plato yang menyatakan bahwa setiap orang memiliki jiwa tripartit. yaitu, Pikiran (logistikon), 
perasaan dan nafsu (epitlzumetikon), rasa baik dan jahat (thumoeides) (Gani et al., 2020).

Dikutip dari laman (vivanews.com, 2020), Mabes Polri memperbarui data angka kriminalitas di seluruh wilayah Tanah Air pada periode Minggu ke-23 dan 24 pandemi Covid-19. Disampaikan bahwa angka kriminalitas di Indonesia pada Minggu ke-24 dibandingkan dengan pekan ke-23 mengalami kenaikan yang signifikan. Berdasarkan data statistik yang dicatat kepolisian bahwa Minggu ke-23 dan ke-24 terjadi kenaikan gangguan Kamtibmas sebesar 38,45 persen atau mengalami kenaikan sebanyak 1.632 kasus. Selain itu, mengutip dari laman (jawapos.com, 2020), Kabid Humas Polda Metro Jaya Kombes Pol. Yusri Yunus menyatakan terjadi peningkatan kejahatan IT seperti hoax, penebar kebencian, menyebarkan berita bohong tentang Covid-19. Melihat dari data dan informasi ini, perlu adanya upaya penanggulangan kejahatan yang memerhatikan aspek kemanusiaan terutama ketika masa pandemi Covid 19.

Dengan diberlakukannya Peraturan Kejaksaan Republik Indonesia Nomor 15 Tahun 2020 Tentang Penghentian Penuntutan Berdasarkan Keadilan Restoratif pada tanggal 22 Juli 2020 sejatinya menjadi suatu terobosan hukum dalam upaya mewujudkan keadilan substantif terutama menghadapi tingkat kriminalitas yang meningkat di masa pandemi. Maka dari itu, dalam penelitian ini akan dikaji terkait bagaimanakah konsep keadilan restoratif dalam Peraturan Kejaksaan Republik Indonesia Nomor 15 Tahun 2020 Tentang Penghentian Penuntutan Berdasarkan Keadilan Restoratif ini serta urgensinya dalam penegakan hukum pidana di masa pandemi Covid 19.

\section{Metode Penelitian}

Penelitian ini merupakan penelitian hukum yuridis-normatif dengan metode pengumpulan data yaitu studi pustaka dan analisis secara deskriptif kualitatif dengan pendekatan filosofis yuridis. Bahan hukum dalam penelitian ini bahan hukum primer yang terdiri dari bahan-bahan hukum yang mempunyai kekuatan mengikat sebagai landasan utama yang dipakai dalam rangka penelitian ini, yang terdiri dari: UndangUndang Republik Indonesia Nomor 11 Tahun 2012 Tentang Sistem Peradilan Anak dan Peraturan Kejaksaan Republik Indonesia Nomor 15 Tahun 2020 Tentang Penghentian Penuntutan Berdasarkan Keadilan Restoratif. Bahan hukum sekunder yang terdiri dari jurnal, buku, dan penelitian yang relevan. Bahan hukum tersier berupa kamus hukum. Untuk menguatkan bahan hukum tersebut. Metode analisis yang digunakan deskriptifkualitatif untuk menjawab rumusan masalah.

\section{Hasil dan Pembahasan}

\section{Penegakan Hukum dan Konsep Keadilan Restoratif}

Sistem hukum merupakan suatu kesatuan yang terdiri dari unsur-unsur yang saling berinteraksi dan bekerja sama satu dengan yang lain untuk mewujudkan suatu tujuan. Sebagai suatu sistem, di dalam hukum tentunya memiliki komponen/ sub sistem yang saling berkaitan sehingga terbentuk suatu sistem. Hukum pidana 
Indonesia mengenal sub sistem hukum pidana materiil, sub sistem hukum pidana formil dan sub sistem hukum pelaksanaan pidana (Bakhri, 2014). Lebih khusus, dalam sub sistem hukum pidana formil dan sub sistem hukum pelaksanaan pidana dikenal sistem peradilan pidana (criminal justice system) sebagai pelaksanaan penegakan hukum pidana di Indonesia.

Perlindungan hukum merupakan suatu hal yang sangat penting dalam aspek penegakan hukum dimana perlindungan hukum secara sederhana diartikan sebagai perlindungan yang diberikan oleh hukum, meliputi adanya hak dan kewajiban (Sumirat, 2017), dalam hal ini yang dimiliki oleh manusia sebagai subyek hukum dalam interaksinya dengan sesama manusia serta lingkungannya sebagai subyek hukum manusia memiliki hak dan kewajiban untuk melakukan suatu tindakan hukum. Jadi, setiap perbuatan manusia tanpa terkecuali diatur oleh hukum (Rochaety, 2016).

Dalam buku John Rawls yang berjudul "A Theory Of Justice” atau yang lebih dikenal dengan "Teori Keadilan" ia mencoba menganalisa kembali permasalahan mendasar dari kajian filsafat politik dengan merekonsiliasikan antara prinsip kebebasan dan prinsip persamaan. John Rawls mengakui bahwa karyanya tersebut sejalan dengan tradisi kontrak sosial (social contract) yang pada awalnya diusung oleh berbagai pemikir kenamaan, seperti John Locke, Jean Jacques Rousseau, dan Immanuel Kant. John Rawls berpendapat bahwa keadilan adalah kebajikan utama dari hadirnya institusi-institusi sosial (social institutions). Akan tetapi, menurutnya, kebaikan bagi seluruh masyarakat tidak dapat mengesampingkan atau mengganggu rasa keadilan dari setiap orang yang telah memperoleh rasa keadilan, khususnya masyarakat lemah. Oleh karena itu, sebagian kalangan menilai cara pandang Rawls sebagai perspektif "liberal-egalitarian of social justice".

Teori keadilan Rawls yang disebut prinsip-prinsip pertama keadilan itu bertolak dari suatu konsep keadilan yang lebih umum yang dirumuskannya sebagai berikut: "All social values liberty and opportunity, income and wealth, and the bases of self-respect are to be distributed equally unless and unequal distribution of any, or all, of these values is to everyone's advantage". (Semua nilai sosial kebebasan dan peluang, pendapatan dan kekayaan, dan landasan harga diri harus dibagikan secara merata kecuali jika distribusi yang tidak merata dari semua atau semua nilai ini adalah untuk keuntungan semua orang (Anshori, 2018).

Terdapat dua hal yang penting yang dapat dicatat sehubungan dengan konsep keadilan umum tersebut. Pertama, kebebasan ditempatkan sejajar dengan nilai-nilai lainnya, dan dengan itu juga konsep umum keadilan tidak memberi tempat istimewa terhadap kebebasan. Hal ini berbeda dengan konsep keadilan Rawls yang berakar pada prinsip hak dan bukan pada prinsip manfaat. Kedua, keadilan tidak selalu berarti semua orang harus selalu mendapatkan sesuatu dalam jumlah yang sama; keadilan tidak selalu berarti semua orang harus diperlakukan secara sama tanpa meperhatikan perbedaan-perbedaan penting yang secara objektif ada pada setiap individu. Maka dari itu, dari hal ini perdamaian manjadi tujuan utama. 
Menurut Ganjar L. Bondan, Keadilan Restoratif secara teoritis dan praktis dapat dipakai dalam penyelesaian suatu tindak pidana dengan penjelasan sebagai berikut :

"Dalam kerangka filosofis, hadirnya pendekatan keadilan restoratif dalam hukum pidana bukan bertujuan untuk mengabolisi hukum pidana, atau melebur hukum pidana dan perdata, karena pendekatan keadilan restoratif mengutamakan jalur mediasi antara korban dan pelaku. Pendekatan keadilan restoratif justru mengembalikan fungsi hukum pidana pada jalurnya semula yaitu pada fungsi ultimum remedium, suatu senjata pamungkas bilamana upaya hukum lain sudah tidak dapat lagi digunakan dalam menghadapi suatu tindak pidana dalam masyarakat. Dalam tataran praktis penanganan dan penyelesaian perkara pidana dengan menggunakan pendekatan keadilan restoratif menawarkan alternatif jawaban atas sejumlah masalah yang dihadapi dalam sistem peradilan pidana, misalnya proses administrasi peradilan yang sulit, lama, dan mahal, penumpukan perkara atau putusan pengadilan yang tidak menampung kepentingan korban” (Zulfa, 2011).

Moh. Hatta, mendefinisikan keadilan restoratif sebagai sebuah konsep pemikiran yang merespon pengembangan sistem peradilan pidana dengan menitikberatkan pada ketertiban masyarakat dan korban yang merasa terpinggirkan oleh mekanisme kerja sistem peradilan pidana saat ini (Hatta, 2016). Keadilan restoratif dibentuk untuk menciptakan rekonsiliasi konflik antara korban dan pelaku dengan melibatkan pemerintah sebagai penegak hukum (Yulia, 2012). Menurut, Andri mediasi yang ada dalam konsep keadilan restoratif adalah gabungan dari victim offender mediation dan reparation negotiation program dimana peradilan tetap dilaksanakan sebagaimana sistem peradilan pidana, namun penegak hukum secara aktif mengambil posisi untuk mendamaikan para pihak (Laksana, 2017). Konsep keadilan restoratif (restorative justice) adalah alternatif yang populer di berbagai belahan dunia untuk penanganan perbuatan melawan hukum (melawan hukum dalam arti formal) karena menawarkan solusi yang komprehensif dan efektif (Tanuwijaya, 2017).

Dalam Undang-Undang Nomor 11 Tahun 2012 tentang Sistem Peradilan Pidana Anak Pasal 1 angka 6 Yang dimaksud dengan keadilan restoratif adalah penyelesaian perkara tindak pidana dengan melibatkan pelaku, korban, keluarga pelaku/korban, dan pihak lain yang terkait untuk bersama-sama mencari penyelesaian yang adil dengan menekankan pemulihan kembali pada keadaan semula, dan bukan pembalasan. Menurut analisa dari Badan Penelitian dan Pengembangan Hukum dan HAM Keadilan restoratif merupakan bentuk keadilan yang berpusat pada kebutuhan korban, pelaku kejahatan, dan masyarakat. Dengan penerapan keadilan restoratif diharapkan mampu memberikan ruang pada masyarakat untuk menangani permasalahan hukum yang dirasakan lebih adil; mengurangi beban negara, misalnya untuk mengurusi tindak pidana yang masih dapat diselesaikan secara mandiri oleh masyarakat, aparat kepolisian, kejaksaan, dan 
pengadilan dapat lebih memfokuskan diri untuk memberantas tindak pidana yang kualifikasinya lebih berbahaya.

Konsep keadilan restoratif mendapat pandangan dari para praktisi hukum, salah satunya wawancara yang dilakukan dengan Bapak Moelyadi, S.H., M.H., C.L.A selaku Ketua DPD IKADIN (Ikatan Advokat Indonesia) D.I. Yogyakarta pada tanggal 19 Mei 2018. Beliau memberikan pendapatnya tentang keadilan restoratif yang dapat disimpulkan sebagai berikut :

1. Keadilan Restoratif menurutnya tidak bisa diterapkan dalam semua kasus hukum, melainkan pada kasus-kasus tertentu yang bisa direstorasi atau dipulihkan dan diketahui secara jelas pihak-pihak yang berkaitan dengan tindak pidana yang dilakukan seperti korban, pelaku kejahatan, maupun masyarakat.

2. Bila semua kasus hukum direstorasi, maka pengadilan sebagai institusi yang menjalankan penegakan hukum akan kehilangan kewibawaannya dalam upaya memberikan efek jera melalui sanksi hukuman penjara dan sanksi lainnya yang telah diatur.

3. Konsep keadilan resoratif sebenarnya telah ada dalam beberapa penanganan kasus kasus hukum seperti kasus pengguna narkoba yang diberi sanksi rehabilitasi dan kasus pidana anak. Namun saat ini belum ada undang-undang yang secara khusus mengatur tentang keadilan restoratif dan selama ini masih ada pada kewenangan dan pendapat dari hakim.

\section{Prinsip-prinsip Keadilan Restoratif}

Yoachim Agus Tridiatno mengemukakan prinsip-prinsip keadilan restoratif sebagai berikut :

a. Keadilan restoratif mengutamakan pemulihan atau restorasi bagi semua pihak yang terkena dampak dari tindak kejahatan, yaitu korban, pelaku, dan masyarakat. Korban adalah pihak pertama yang paling dirugikan oleh karena kejahatan. Korban secara langsung menderita oleh karena kejahatan. Ia menderita secara fisik dan mental bahkan kerugian moril maupun materil. Pelaku kejahatan juga menderita kerugian (Tridiatno, 2015).

b. Keadilan restoratif fokus pada kebutuhan tiga pihak, yaitu korban, pelaku kejahatan, dan masyarakat, yang tidak dipenuhi oleh proses peradilan. Dalam proses peradilan korban tindak kejahatan diabaikan, karena tindak kejahatan dimengerti sebagai tindakan yang melawan atau merugikan negara. Peranan korban diambil oleh negara sehingga negaralah yang mempunyai tanggungjawab menghukum pelaku tindak kejahatan, sementara korban tidak mendapatkan hak apapun. Hukuman yang diberikan pada pelaku tindak kejahatan seringkali sama sekali tidak berkaitan dengan penderitaan korban, Oleh karena itu, keadilan restoratif akan fokus pada kebutuhan korban.

c. Keadilan restorarif memperhatikan kewajiban dan tanggungjawab yang muncul karena tindak kejahatan. Pelaku kejahatan wajib memulihkan kerusakan yang diderita korban, dan masyarakat. Kewajiban pertama dilakukan dengan mengakui kesalahan pada korban. Pengakuan ini menjadi penting, karena merupakan bukti 
pengakuan atas penderitaan yang dialami korban. Hal ini merupakan proses yang penting dalam menyembuhkan luka-luka batin dan penderitaan mental korban. Setelah itu, pelaku kejahatan mempunyai kewajiban untuk memulihkan penderitaan fisik dan kerugian material lainnya. Pelaku kejahatan juga harus meminta maaf pada masyarakat atau orang yang dipercaya untuk mewakilinya. Serta mengganti kerugian material yang terjadi di masyarakat akibat tindakan kejahatan yang dilakukakan. Kewajiban korban untuk menerima pengakuan dari pelaku kejahatan dan memafkannya. Begitu pula masyarakat diwajibkan untuk menerima pengakuan dari pelaku kejahatan dan memaafkannya. Dengan demikian akan terjadi rekonsiliasi dan perdamaian kembali.

Sementara itu, Rufinus Hotmaulana Hutauruk (Hutauruk, 2013) mengemukakan terdapat beberapa prinsip yang berlaku secara universal yang melekat dalam konsep pendekatan restoratif dalam menyelesaikan tindak pidana, antara lain: Prinsip Penyelesaian yang Adil, Prinsip Perlindungan yang Setara, Prinsip Hak-Hak Korban, Prinsip Proporsionalitas, Prinsip Praduga Tak Bersalah, Prinsip Hak Bantuan Konsultasi atau Penasihat Hukum.

\section{Analisa Konsep Keadilan Restoratif dalam Peraturan Kejaksaan Republik Indonesia Nomor 15 Tahun 2020 Tentang Penghentian Penuntutan Berdasarkan Keadilan Restoratif}

Pendekatan keadilan restoratif diasumsikan sebagai pergeseran paling mutakhir dari berbagai model dan mekanisme yang bekerja dalam sistem peradilan pidana pada saat ini. PBB melalui Basic Principles yang telah digariskannya menilai bahwa pendekatan keadilan restoratif adalah pendekatan yang dapat dipakai dalam sistem peradilan pidana yang rasional. Hal ini sejalan dengan pandangan G.P. Hoefnagels yang menyatakan bahwa politik kriminal harus rasional (a rational total of the responses to crime) (Zulfa, 2011).

Dalam menjawab permasalahan berkaitan penyelesaian perkara pidana yang selalu berujung pada penghukuman pidana penjara, maka alternatif penyelesaian muncul berkaitan dengan kewenangan penuntut umum menghentikan penuntutan berdasarkan konsep keadilan restoratif yaitu Peraturan Kejaksaan RI No. 15 tahun 2020 tentang Penghentian Penuntutan Berdasarkan Keadilan Restoratif, yang selanjutnya disebut dengan Perja No. 15 tahun 2020, perlu diberikan apresiasi karena dalam konsep ini melibatkan pelaku, korban, dan masyarakat dalam proses penyelesaian perkara pidana tersebut. "Pendekatan keadilan restoratif" yang dimaksud ini lebih dititikberatkan pada kesepakatan perdamaian antara pelaku dan korban dan bagaimana kemudian hukum acara mengakui keberadaan kesepakatan perdamaian tersebut sebagai kesepakatan yang memiliki kekuatan hukum. Namun demikian apa yang perlu mendapatkan perhatian adalah jangan sampai penerapan pendekatan keadilan restoratif ini diartikan sebagai sebatas sebuah kesepakatan perdamaian karena jika demikian proses yang berjalan justru akan terjebak pada sebatas menjalankan fungsi secara prosedur saja sehingga kebenaran (khususnya kebenaran materil) dan keadilan tidak dapat tercapai (Widjayanti, 2021). 
Dalam Pasal 2 Peraturan Kejaksaan Republik Indonesia Nomor 15 Tahun 2020 Tentang Penghentian Penuntutan Berdasarkan Keadilan Restoratif, Penghentian penuntutan berdasarkan keadilan restoratif dilaksanakan dengan berasaskan:
a. keadilan;
b. kepentingan umum;
b. proporsionalitas;
c. pidana sebagai jalan terakhir; dan
d. cepat, sederhana, dan biaya ringan.

Dari ketentuan asas diatas, dapat dicermati bahwa Peraturan Kejaksaan terkait penghentian penuntutan berdasarkan keadilan restoratif yang dimaksud sejalan dengan prinsip-prinsip keadilan restoratif secara umum serta menempatkan proses pidana sebagai jalan terakhir dengan mengedapankan aspek keadilan dan kepentingan umum. Selain itu, proses ini juga mendukung perbaikan sistem peradilan pidana yang mengedapankan asas cepat, sederhana, dan biaya ringan. Sementara itu, terkait syarat dan ketentuan terkait penghentian penuntutan ini terdapat dalam pasal 4 dan pasal 5 yang menyebutkan:

\section{Pasa1 4}

1. Penghentian penuntutan berdasarkan Keadilan Restoratif dilakukan dengan memperhatikan:
a. kepentingan Korban dan kepentingan hukum lain yang dilindungi;
b. penghindaran stigma negatif;
b. penghindaran pembalasan;
c. respon dan keharmonisan masyarakat; dan
d. kepatutan, kesusilaan, dan ketertiban umum.

2. Penghentian penuntutan berdasarkan Keadilan Restoratif sebagaimana dimaksud pada ayat (1) dilakukan dengan mempertimbangkan:
a. subjek, objek, kategori, dan ancaman tindak pidana;
b. latar belakang dilakukannya tindak pidana;
c. tingkat ketercelaan;
e. kerugian atau akibat yang ditimbulkan dari tindak pidana;
f. cost and benefit penanganan perkara;
g. pemulihan kembali pada keadaan semula; dan
h. adanya perdamaian antara Korban dan Tersangka.

\section{Pasal 5}

1. Perkara tindak pidana dapat ditutup demi hukum dan dihentikan penuntutannya berdasarkan Keadilan Restoratif dalam hal terpenuhi syarat sebagai berikut:

a. tersangka baru pertama kali melakukan tindak pidana;

b. tindak pidana hanya diancam dengan pidana denda atau diancam dengan pidana penjara tidak lebih dari 5 (lima) tahun; dan 
c. tindak pidana dilakukan dengan nilai barang bukti atau nilai kerugian yang ditimbulkan akibat dari tindak pidana tidak lebih dari Rp2.500.000,00 (dua juta lima ratus ribu rupiah).

2. Untuk tindak pidana terkait harta benda, dalam hal terdapat kriteria atau keadaan yang bersifat kasuistik yang menurut pertimbangan Penuntut Umum dengan persetujuan Kepala Cabang Kejaksaan Negeri atau Kepala Kejaksaan Negeri dapat dihentikan penuntutan berdasarkan Keadilan Restoratif dilakukan dengan tetap memperhatikan syarat sebagaimana dimaksud pada ayat (1) huruf a disertai dengan salah satu huruf $b$ atau huruf $c$.

3. Untuk tindak pidana yang dilakukan terhadap orang, tubuh, nyawa, dan kemerdekaan orang ketentuan sebagaimana dimaksud pada ayat (1) huruf c dapat dikecualikan.

4. Dalam hal tindak pidana dilakukan karena kelalaian, ketentuan pada ayat (1) huruf $\mathrm{b}$ dan huruf $\mathrm{c}$ dapat dikecualikan.

5. Ketentuan sebagaimana dimaksud pada ayat (3) dan ayat (4) tidak berlaku dalam hal terdapat kriteria/keadaan yang bersifat kasuistik yang menurut pertimbangan Penuntut Umum dengan persetujuan Kepala Cabang Kejaksaan Negeri atau Kepala Kejaksaan Negeri tidak dapat dihentikan penuntutan berdasarkan Keadilan Restoratif.

6. Selain memenuhi syarat dan ketentuan sebagaimana dimaksud pada ayat (1), ayat (2), ayat (3), dan ayat (4), penghentian penuntutan berdasarkan Keadilan Restoratif dilakukan dengan memenuhi syarat:

a. telah ada pemulihan kembali pada keadaan semula yang dilakukan oleh Tersangka dengan cara:

1) mengembalikan barang yang diperoleh dari tindak pidana kepada Korban;

2) mengganti kerugian Korban;

3) mengganti biaya yang ditimbulkan dari akibat tindak pidana; dan/atau memperbaiki kerusakan yang ditimbulkan dari akibat tindak pidana;

b. Telah ada kesepakatan perdamaian antara Korban dan Tersangka; dan

c. Masyarakat merespon positif.

7. Dalam hal disepakati Korban dan Tersangka, syarat pemulihan kembali pada keadaan semula sebagaimana dimaksud pada ayat (6) huruf a dapat dikecualikan.

8. Penghentian penuntutan berdasarkan Keadilan Restoratif dikecualikan untuk perkara:

a. Tindak pidana terhadap keamanan negara, martabat Presiden dan Wakil Presiden, negara sahabat, kepala negara sahabat serta wakilnya, ketertiban umum, dan kesusilaan;

b. Tindak pidana yang diancam dengan ancaman pidana minimal;

c. Tindak pidana narkotika;

d. Tindak pidana lingkungan hidup; dan

e. Tindak pidana yang dilakukan oleh korporasi 
Dalam menerapkan kebijakan ini, instansi kejaksaan juga harus berhati-hati agar kepastian hukum tetap menjadi pilar utama. Kebijakan kriminalisasi atau dekriminalisasi yang terjadi dalam perkembangan hukum justru jangan sampai menghambat tujuan mulia dari Peraturan Kejaksaan ini. Begitu juga kebijakan dekriminalisasi dengan menghilangkan suatu tindak pidana menjadi bukan suatu tindak pidana lagi harus menjadi perhatian dari proses penghentian penuntutan.

Kepastian hukum mengenai keadilan dalam penangan suatu perkara menjadi salah satu hal yang utama. Pemenuhan asas kepastian dalam Perja Nomor 15 Tahun 2020, berdasarkan teori cita hukum oleh Gustav Rudbruch, keadilan, kepastian, dan kemanfaatan tidak mungkin terpenuhi dalam satu waktu. Maka dari itu, Kejaksaan mengeluarkan Perja dilihat dari segi muatan hukumnya lebih untuk menjunjung tinggi keadilan. Sedangkan untuk kepastian hukumnya, Perja ini harus disesuaikan dengan ketentuan yang ada dalam KUHAP agar tidak jauh menyimpangi atau melanggar sehingga memliki kepastian hukum yang kuat.

Salah satu yang menjadi kelemahan dalam Perja ini adalah kepastian hukum yang terdapat dalam Pasal 5 ayat (5), yang menyebutkan untuk tindak pidana ayat (3) dan (4) tidak berlaku dalam hal terdapat keadaan kasuistik yang menurut pertimbangan Penuntut Umum dengan persetujuan Kepala Cabang Kejaksaan Negeri atau Kepala Kejaksaan Negeri tidak dapat dihentikan penuntutan. Sedangkan dalam Perja ini sendiri tidak ada informasi terkait apa parameter yang digunakan Penuntut Umum dalam memutuskan suatu kasus perkara pidana terdapat kasuistik atau tidak, sehingga jika merujuk pada pasal ini ukuran kasus seperti apa yang bisa atau tidak bisa dihentikan berdasarkan Keadilan Restoratif masih belum pasti. Maka dari itu, Pasal 5 ayat (5) ini bisa menjadi celah untuk masalah dan juga multitafsir dalam pengaplikasian tindak pidana ayat (3) dan (4).

\section{Urgensi Pendekatan Keadilan Restoratif dalam Penegakan Hukum di Masa Pandemi Covid 19}

Menurut data terakhir jumlah penghuni lapas per kantor wilayah (Kanwil), dikutip dari http://smslap.ditjenpas.go.id/ bulan September 2020, hanya ada 8 provinsi yang jumlah penghuni lapasnya tidak melebihi kapasitas, yaitu D.I. Yogyakarta, Gorontalo, Maluku, Maluku Utara, Nusa Tenggara Timur, Papua, Sulawesi Barat, dan Sulawesi Utara. Sisanya atau sekitar 25 Provinsi lainnya melebihi kapasitas. Dari data tersebut maka perlu adanya alternatif pemidanaan serta tata kelola Lembaga Pemasyarakatan yang lebih baik selain dari program asimilasi sehingga narapidana mendapatkan hak asasinya dengan baik, terutama di masa pandemi Covid 19 yang belum juga berakhir.

Kejaksaan sebagai bagian dari sistem peradilan pidana pada hakikatnya merupakan satu-satunya lembaga yang mempunyai fungsi di bidang penuntutan dan fungsi lain yang secara tegas disebutkan dalam Pasal 2 ayat (1) UU RI Nomor 16 Tahun 2004 tentang Kejaksaan Republik Indonesia. Enn en ondeelbaar yang berarti 
kejaksaan adalah satu dan tidak terpisahkan, merupakan satu landasan dalam pelaksanaan tugas dan wewenangnya di bidang penuntutan yang bertujuan memelihara kesatuan kebijakan di bidang penuntutan sehingga dapat menampilkan ciri khas yang menyatu dalam tata pikir, tata laku, dan tata kerja Kejaksaan. Keberadaan Kejaksaan sebagai institusi penegak hukum pidana mempunyai kedudukan sentral dan peran yang strategis sebagai pengendali perkara (dominus litis), dan sebagai filter antara proses penyidikan dan proses pemeriksaan di persidangan, serta sebagai eksekutor terhadap sebuah putusan peradilan pidana yang telah mempunyai kekuatan hukum tetap (in kracht van gewijsde).

Di masa Pandemi Covid 19, semua orang dapat berbicara tentang penegakan hukum tetapi tidak semua dapat mendudukkannya dalam keadaan yang objektif, karena sebagian besar melihat dari sudut subyektifitas masing-masing tergantung dari mana perspektif orang tersebut memandangnya. Keadaan semacam ini berpotensi membahayakan eksistensi hukum dan penegakannya itu sendiri. Penegakan hukum seolah tersandera dan dipaksa untuk memperhatikan dan bertitik tolak dari sudut pandang masing-masing orang yang berkepentingan. Setiap langkah aparat penegak hukum diminta memperhatikan dan berdiri di atas kepentingan individu atau pun kelompok golongan satu persatu.

Undang-Undang Nomor 6 Tahun 2018 tentang Kekarantinaan Kesehatan, khususnya pasal 93 memang sudah mengatur tentang aturan bagi pelanggar pembatasan sosial berskala besar (PSBB) memberikan ancaman sanksi pidana paling lama 1 (satu) tahun dan/atau pidana denda paling banyak Rp.100.000.000,00 (seratus juta rupiah) Selain Pasal 218 KUHP dinyatakan adanya ancaman pidana penjara paling lama empat bulan dua minggu atau pidana denda paling banyak sembilan ribu rupiah bagi siapa saja pada waktu rakyat datang berkerumun dengan sengaja tidak segera pergi setelah diperintah tiga kali oleh atau atas nama penguasa yang berwenang. Hal ini kemudian ditindaklanjuti pemerintah dengan mengeluarkan Peraturan Pemerintah (PP) Nomor 21 Tahun 2020 tentang Pembatasan Sosial Berskala Besar (PSBB). Karenanya, saat Peraturan Pemerintah telah resmi dikeluarkan, maka pihak kepolisian sebagaimana amanat Presiden secara tegas melakukan tindakan upaya penegakan hukum bagi pelanggarnya. Artinya, pencegahan wabah pandemi Covid-19 ini harus dilakukan dengan memberikan sanksi pidana bagi masyarakat yang melakukan pelanggaran. Melalui Maklumat Kapolri Nomor Mak/2/III/2020 tentang Kepatuhan Terhadap Kebijakan Pemerintah dalam Penanganan Penyebaran Virus Corona, kemudian pihak kepolisian melakukan tindakan mengamankan masyarakat yang tidak menaati aturan mengenai PSBB tersebut (Yunus, 2020).

Adanya krisis kepercayaan terhadap penegakan hukum di Indonesia ini tentunya harus segera dipulihkan. Masyarakat tampaknya sudah terdoktrin dengan kata-kata "hukum hanya tajam ke bawah", sehingga masyarakat cenderung jenuh dan putus asa terhadap proses penegakan hukum yang dinilai tidak mencerminkan rasa keadilan. Hal tersebut memunculkan fenomena "hukum masyarakat" yang 
sebenarnya lebih mencerminkan sikap arogansi namun justru dianggap lebih adil dan obyektif bagi masyarakat. Para pelaku kejahatan terutama tindak pidana ringan oleh masyarakat diadili sendiri tanpa melalui prosedur hukum, baik melalui peradilan fisik atau pun peradilan opini. Selain itu sikap protes yang menunjukkan keberanian berlebihan terhadap aparat penegak hukum tidak jarang menimbulkan gesekan dan kejadian anarkis yang akhirnya terkesan merendahkan wibawa penegakan hukum itu sendiri. Kejadian semacam ini tidak lepas dari adanya dua benturan kepentingan, yaitu kepentingan penegakan hukum untuk kepastian hukum berdasarkan peraturan perundang-undangan, dan kepentingan penegakan hukum untuk kepentingan keadilan dalam masyarakat. Terutama di masa pandemi Covid 19 yang menunjukan kriminalitas meningkat, maka tidak dapat dipungkiri aksi main hakim sendiri bisa terus terjadi.

Keadilan Restoratif menjadi salah satu jalan dalam menyelesaikan persoalan hukum dengan memerhatikan kewajiban dan tanggungjawab yang muncul karena tindak kejahatan yang dilakukan. Hal ini menjadi prinsip dari keadilan restoratif yang menekankan pada aspek pemulihan bagi semua pihak yang terkena dampak dari tindak kejahatan. Maka dari itu, konsep ini sudah selayaknya dikembangkan di tanah air sebagai negara hukum yang berlandaskan Pancasila sehingga sesuai dengan kondisi masyarakat dan budaya yang ada. Bagir Manan menguraikan tentang substansi "restorative justice" yang berisi prinsip-prinsip, antara lain: "Membangun partisipasi bersama antara pelaku, korban, dan kelompok masyarakat menyelesaikan suatu peristiwa atau tindak pidana; Menempatkan pelaku, korban, dan masyarakat sebagai "stakeholders" yang bekerja bersama; dan langsung berusaha menemukan penyelesaian yang dipandang adil bagi semua pihak (win-win solutions) (Makarao, 2013). Antara keadilan dan ketidakadilan adalah dua kategori yang saling berkaitan satu dengan lainnya, seperti ungkapan Roxanne Varzi, "there is no justce without crime" (tidak pernah ada keadilan tanpa didahului oleh suatu tindak kejahatan) yang dipresepsikan sebagai suatu bentuk ketidakadilan. Maka dalam mewujudkan suatu perdamaian, konsekuensi logisnya ialah bagaimana menjadikan keadilan yang bersifat filosofis dan subjektif pada setiap orang mampu diejawantahkan dalam sebuah peraturan hukum sehingga mampu menciptakan perdamaian abadi (Bakir, 2015).

Saat ini publik menginginkan penegakan hukum yang tidak selalu kaku dan saklek dengan bunyi peraturan perundang-undangan, tetapi lebih kepada hukum yang mengalir. Adanya reorientasi cara pandang publik terhadap penegakan hukum seperti ini tentunya harus dibarengi dengan aparat penegak hukum yang responsif untuk mewujudkan penegakan hukum yang tidak hanya menggunakan teori formalpositivistis. Aparat penegak hukum dituntut untuk tidak sekedar melaksanakan tugasnya dengan hanya bertumpu pada satu kaki melalui pendekatan undang-undang saja, dengan asal sekedar memenuhi unsur ketentuan bunyi pasal maka dikatakan sudah terpenuhi semua syaratnya. Aparat penegak hukum sekarang harus juga menggunakan pendekatan kasus dengan menelaah beberapa kasus untuk bahan 
referensi, serta pendekatan konseptual dengan beranjak dari pandangan dan doktrin yang berkembang yang nantinya dapat melahirkan ide dan konsep hukum yang relevan.

Sejatinya aparat penegak hukum diminta untuk tidak hanya terpaku pada norma hukum apa yang dilarang atau dianjurkan, tetapi diminta berpikir lebih jauh lagi sampai ke batas akibat apa yang dapat ditimbulkan dari penegakan hukum terhadap larangan atau pun anjuran norma hukum tersebut. Para aparat penegak hukum diharapkan bisa mendobrak paham positivisme yang kaku dengan lebih mengedepankan nilai-nilai keadilan dan hati nurani namun tetap dalam koridor hukum yang berlaku.

Sebagai manifestasi konkrit dari sebuah paradigma pemidanaan bukan untuk pembalasan melainkan sebagai pemulihan, Kejaksaan melakukan langkah strategis dengan mengeluarkan Peraturan Kejaksaan RI Nomor 15 Tahun 2020 tentang Penghentian Penuntutan Berdasarkan Keadilan Restoratif yang diundangkan tepat pada Hari Bhakti Adhyaksa (HBA) tanggal 22 Juli 2020. Peraturan ini sebagai substansi hukum (legal substance) diformulasikan untuk mengeliminasi paham rigid positivistik dengan lebih mengedepankan hukum progresif berlabel keadilan restoratif (restorative justice). Adapun keadilan restoratif merupakan penyelesaian perkara tindak pidana dengan melibatkan pelaku, korban, keluarga pelaku/korban, dan pihak lain yang terkait untuk bersama-sama mencari penyelesaian yang adil dengan menekankan pemulihan kembali pada keadaan semula dan bukan pembalasan.

Di dalam ketentuan kitab induk hukum pidana formil (KUHAP), tidak semua penegakan hukum harus berakhir di pengadilan. Kriteria dalam hal tidak terdapat cukup bukti, atau peristiwa tersebut ternyata bukan merupakan tindak pidana, atau pun perkara ditutup demi hukum, maka Penuntut Umum menghentikan penuntutan dengan menuangkan dalam Surat Ketetapan. Perkara ditutup demi hukum dapat disebabkan karena terdakwa meninggal dunia, perkara daluwarsa, nebis in idem ${ }_{s}$ atau pun delik aduan yang ditarik kembali dalam batas waktu yang ditentukan.

Secara normatif memang tidak ada alasan penghentian penuntutan karena keadilan restoratif dalam peraturan setara undang-undang, namun demikian secara faktual ungkapan ubi societes ibi ius yang berarti dimana ada masyarakat disitu ada hukum membawa konsekuensi bahwa hukum harus terus berkembang sebagaimana perkembangan masyarakat. Tidak terkecuali dengan ketentuan peraturan proses penegakan hukum pidana yang menjadi dasar aparat penegak hukum dalam melaksanakan tugas hukum formilnya tentunya dituntut untuk terus relevan dengan perkembangan masyarakat sehingga klausul-klausulnya pun harus terus disesuaikan.

Pengaturan penghentian penuntutan karena keadilan restoratif secara tegas dalam sebuah Peraturan Kejaksaan menjadi pijakan bagi komponen sistem hukum berikutnya yaitu struktur hukum (legal structure) dalam melaksanakan tugasnya. Terutama di masa pandemi Covid 19, Jaksa sebagai aparat penegak hukum diminta untuk bisa mengedepankan nilai-nilai keadilan dan hati nurani namun tetap dalam 
jalur hukum yang berlaku. Hasil kerja dari struktur hukum itulah yang nantinya diharapkan membentuk pola pikir (mindset) hukum progresif yang dipercaya dalam masyarakat sebagai budaya hukum secara kausalitas dan berkesinambungan. Sebagaiamana dikemukakan oleh Dignan bahwa keadilan restoratif menjadi sebuah sikap dan nilai dasar yang digunakan dalam merespons perkara pidana. Diharuskan adanya keseimbangan fokus perhatian antara kepentingan pelaku dan korban serta memperhitungkan dampak penyelesaian perkara pidana tersebut terhadap masyarakat (Mahendra, 2020).

Dalam melakukan kebijakan hukum di masa pandemi Covid 19 ini, pemerintah harus bisa meminimalkan kematian dari penyakit coronavirus 2019 (Covid-19) dan dampak ekonomi dari penyebaran virus. Meminimalisir kematian serendah mungkin akan menjadi prioritas tertinggi bagi individu, karenanya pemerintah harus menerapkan langkah-langkah untuk memperbaiki krisis ekonomi yang tak terhindarkan serta kebijakan hukum yang bijaksana sehingga sejatinya sanksi pidana baik penjara maupun denda bukanlah kebijakan yang bijak ditengah krisis ekonomi dan situasi yang tak menentu di masyarakat sekarang (Firdaus, 2020). Maka dari itu, dengan adanya Perja Nomor 15 Tahun 2020 ini selayaknya diterapkan secara baik demi mewujudkan keadilan di masyarakat ditengah kondisi pandemi dan diupayakan tetap melaksanakan protokol kesehatan sehingga upaya-upaya perdamaian sebagaimana yang telah diatur dapat dilaksanakan secara baik.

Sejalan dengan pandangan David Easton ketika pemerintah membuat kebijakan publik, ketika itu pula pemerintah mengalokasi nilai-nilai kepada masyarakat, karena setiap kebijakan mengadung seperangkat nilai di dalamnya. Sebagai contoh, ketika pemerintah menetapkan Undang-Undang No. 22 Tahun 1999, nilai yang akan dikejar adalah penghormatan terhadap nilai demokrasi dan pemberdayaan terhadap masyarakat dan pemerintah daerah (Taufiqurokhman, 2014). Dalam hal ini, Peraturan Kejaksaan harus diterapkan dengan mekanisme dan fasilitas yang memadai sehingga masyarakat dapat menerimanaya. Terutama ketika Perja ini sah diberlakukan di masa pandemi Covid 19. Semua ketentuan dan mekanisme harus dijalankan aparat penegak hukum dengan adil dikala meningkatnya kriminalitas di masa pandemi Covid 19.

Dalam konteks penerapan Peraturan Kejaksaan ini, keadilan restoratif harus ditujukan pada suatu solusi penyelasaian hukum terutama pada tindak pidana ringan sebagaimana dalam ketentuan Perja tersebut. Sehingga ketika pelaku dan korban sepakat untuk berdamai, masyarakat juga ikut terlibat dalam hal penyelsaian perdamaian sehingga tercipta kembali kondisi ketertiban dan kemanan seperti semula. Sebagaimana peneltian yang telah dilakukan oleh Chalida Hanum dalam VERITAS: Jurnal Program Pascasarjana Ilmu Hukum Vol. 7 No. 1 Maret 2021 Peraturan Kejaksaan Republik Indonesia Nomor 15 tahun 2020 tentang Penghentian Penuntutan Berdasarkan Keadilan Restoratif diakui keberadaannya dalam Undangundang Nomor 12 Tahun 2011 tentang Tata Cara Pembentukan Peraturan Perundang-Undangan. Selain itu ketegori/jenis peraturan tersebut tergolong dalam 
peraturan yang bersifat khusus yang mana tunduk pada prinsip lex specialis derogat legi generalis. Maka dengan demikian sejatinya Perja ini harus lebih ditingkatkan lagi kedudukan hukumnya sehingga bisa menjadi Undang-Undang tersendiri kedepan (Hanum, 2021).

Perlu diperhatikan bahwa implementasi kebijakan merupakan tahapan yang sangat penting dalam keseluruhan struktur kebijakan, karena melalui prosedur ini proses kebijakan secara keseluruhan dapat dipengaruhi tingkat keberhasilan atau tidaknya pencapaian tujuan. Hal ini dipertegas oleh Chief J.O. Udoji (1981) yang mengatakan bahwa pelaksanaan kebijakan adalah sesuatu yang sangat penting daripada pembuatan kebijakan. Dalam hal implementasi Peraturan Kejaksaan ini sejatinya kepentingan korban adalah yang utama sehingga korban harus benar-benar menyepakati upaya penghentian penuntutan ini tanpa ada paksaan sehingga prosesnya dilakukan secara transparan dan berkeadilan. Dengan adanya Peraturan Kejaksaan ini, kasus-kasus pidana ringan di masa pandemi Covid 19 serta kasuskasus yang menyayat hati dan menciderai rasa keadilan seperti kasus mbok minah yang mencuri 3 biji kakao tidak selayaknya lagi masuk ke meja hakim dipersidangan.

\section{Kesimpulan}

Penegakan keadilan dalam kehidupan bermasyarakat memiliki arti yang sangat penting dalam upaya membangun peradaban bangsa yang tinggi dan bermartabat. Hukum positf terkadang tidak sepenuhnya menjamin rasa keadilan, dan sebaliknya rasa keadilan seringkali tidak memiliki kepastian hukum, sehingga jalan tengahnya adalah bagaimana agar hukum positif yang ada selalu merupakan cerminan dari rasa keadilan itu. Sejalan dengan hal itu, melalui Peraturan Kejaksaan Republik Indonesia Nomor 15 Tahun 2020 Tentang Penghentian Penuntutan Berdasarkan Keadilan Restoratif, instansi kejaksaan berupaya untuk mengedapankan nilai-nilai keadilan memerhatikan kondisi dari para pihak terutama korban dan pelaku kejahatan sehingga jalur pidana menjadi jalan terkahir. Hal ini berkaitan dengan kondisi pandemi Covid 19 dimana angka kriminalitas meningkat terutama pidana ringan hanya untuk mencukupi kebutuhan sehari-hari atau kebutuhan belajar anak-anak yang memerlukan perangkat gadget untuk belajar dimana di beberapa daerah hal tersebut cukup sulit didapatkan. Oleh karena itu, setelah dilakukan analisa, Peraturan Kejaksaan Republik Indonesia Nomor 15 Tahun 2020 Tentang Penghentian Penuntutan Berdasarkan Keadilan Restoratif secara muatan hukum sudah memenuhi aspek keadilan dan prinsip-prinsip umum keadilan restoratif dengan mengedepankan upaya pengembalian kembali kepada kondisi semula dengan melibatkan para pihak terutama korban dan pelaku. Selain itu, peraturan ini pun sesuai apabila dilakukan diluar kondisi pandemi atau dalam kondisi normal karena pada dasarnya keadilan merupakan hal terpenting setiap warga negara. Namun demikian, perbaikan terhadap muatan hukum Peraturan Kejaksaan ini harus terus dilakukan salah satunya pada konteks kasusistik yang harus diperjelas dan kesesuaian dengan peraturan yang terdapat dalam KUHAP. 
Implementasi dari Peraturan ini merupakan bagian terpenting sehingga aspek keadilan bisa tercapai. Maka dari itu, praktik dari keadilan restoratif ini seyogyanya harus dilandasi dengan peran serta aparat penegak hukum yang mengedepankan hati nurani dan nilai-nilai moral sehingga diharapkan penegakan hukum di Indonesia kedepan semakin baik serta mampu mengembalikan kepercayaan publik dalam upaya penegakan hukum dan keadilan. Selain itu, dalam menerapkan Peraturan Kejaksaan Republik Indonesia Nomor 15 Tahun 2020 Tentang Penghentian Penuntutan Berdasarkan Keadilan Restoratif, penegak hukum harus memahami mekanisme dan teknisnya sehingga instansi kejaksaan harus melakukan bimbingan teknis atau pendidikan pelatihan yang berkelanjutan sehingga peraturan ini dapat diterapkan dengan baik. 


\section{BIBLIOGRAFI}

Anshori, Abdul Ghofur. (2018). Filsafat hukum. Ugm Press.Google Scholar

Bakhri, Syaiful. (2014). Sistem peradilan pidana Indonesia dalam perspektif pembaruan, teori, dan praktik peradilan. Pustaka Pelajar.Google Scholar

Bakir, Herman. (2015). Filsafat Hukum: Tema-tema Fundamental Keadilan dari Sisi Ajaran Fiat Justitia Ruat Caelum. Google Scholar

Burhanuddin, Andi Iqbal, Massi, Muh Nasrum, Thahir, Hasanuddin, Razak, Amran, \& Surungan, Tasrief. (2020). Merajut Asa Di Tengah Pandemi Covid-19 (Pandangan Akademisi UNHAS). Deepublish. Google Scholar

Gani, Nur Salwiyani, Fitriana, A. Dian, Sila, Anugrahwati M., Fitriani, R., Yuliarti, Astinana, Thalib, Fajar, Hermansyah, Bambang, Aslam, Muhammad, Sahid, Muhammad, \& Umar, Nugrah Juniar. (2020). Covid 19 Dalam Bingkai Komunikasi. IAIN Parepare Nusantara Press. Google Scholar

Hatta, Mohammad Hatta. (2016). Kapita selekta pembaharuan hukum pidana dan sistem pemidanaan. Liberty. Google Scholar

jawapos.com September 23). (2020). https://www.jawapos.com/nasional/hukumkriminal/10/04/2020/selama-pandemi-covid-19-tren-penyebaran-hoax-meningkat/.

Mahendra, Adam Prima. (2020). Mediasi Penal Pada Tahap Penyidikan Berlandaskan Keadilan Restoratif. Jurist-Diction, 3(4), 1153-1178. Google Scholar

Makarao, M. Taufik. (2013). Pengkajian hukum tentang penerapan restorative justice dalam penyelesaian tindak pidana yang dilakukan oleh anak-anak. Badan Pembinaan Hukum Nasional, Jakarta. Google Scholar

Rochaety, Nur. (2016). Menegakkan HAM Melalui Perlindungan Hukum bagi Perempuan Korban Kekerasan di Indonesia. PALASTREN Jurnal Studi Gender, 7(1), 1-24. Google Scholar

Sumirat, Iin Ratna. (2017). Perlindungan Hukum terhadap Perempuan dan Anak Korban Kejahatan Perdagangan Manusia. Jurnal Studi Gender Dan Anak, 3(01), 19-30. Google Scholar

Taufiqurokhman. (2014). Kebijakan Publik Pendelegasian Tanggungjawab Negara Kepada Presiden Selaku Penyelenggara Pemerintahan. Jakarta: FISIP Universitas Moestopo Beragama (Pers).

Tridiatno, Yoachim Agus. (2015). Keadilan Restoratif. Yogyakarta: Cahaya Atma Pustaka. Google Scholar

vivanews.com. (2020). 
Konsep Keadilan Restoratif dalam Penegakan Hukum Pidana Di Masa Pandemi Covid

Zulfa, Eva Achjani. (2011). Reparasi dan Kompensasi Korban Dalam Restorative Justice. Lembaga Perlindungan Saksi Dan Korban Dan Departemen Kriminologi FISIP UI, Jakarta. Google Scholar

\section{Copyright holder :}

Muhammad Rafi Urrutab (2021)

First publication right :

Syntax Idea

This article is licensed under:

(c) (i) (? 